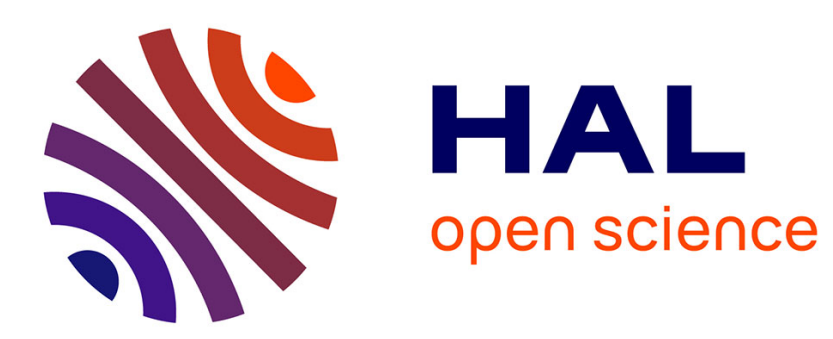

\title{
Disguised Subjectivity in Two Chinese Fictional Dream Narratives of the Qing
}

Aude Lucas

\section{To cite this version:}

Aude Lucas. Disguised Subjectivity in Two Chinese Fictional Dream Narratives of the Qing. ExtrêmeOrient Extrême-Occident, 2018, 42, pp.179-203. 10.4000/extremeorient.1015 . hal-02126763

\section{HAL Id: hal-02126763 \\ https://hal.science/hal-02126763}

Submitted on 18 May 2021

HAL is a multi-disciplinary open access archive for the deposit and dissemination of scientific research documents, whether they are published or not. The documents may come from teaching and research institutions in France or abroad, or from public or private research centers.
L'archive ouverte pluridisciplinaire HAL, est destinée au dépôt et à la diffusion de documents scientifiques de niveau recherche, publiés ou non, émanant des établissements d'enseignement et de recherche français ou étrangers, des laboratoires publics ou privés. 


\section{Disguised Subjectivity in Two Chinese Fictional Dream Narratives of the Qing}

Subjectivité voilée dans deux récits oniriques chinois de fiction des Qing 中國前現代故事文學中夢境敘述文的微妙主觀性

\section{Aude Lucas}

\section{OpenEdition}

\section{Journals}

Electronic version

URL: http://journals.openedition.org/extremeorient/1015

DOI: 10.4000/extremeorient. 1015

ISBN: 978-2-84292-990-9

ISSN: 2108-7105

\section{Publisher}

Presses universitaires de Vincennes

\section{Printed version}

Date of publication: 1 December 2018

Number of pages: $179-203$

ISBN: 978-2-84292-988-6

ISSN: 0754-5010

Electronic distribution by Cairn

\section{CAIRN INFO}

CHERCHER, REPÉRER, AVANCER

\section{Electronic reference}

Aude Lucas, «Disquised Subjectivity in Two Chinese Fictional Dream Narratives of the Qing », Extrême-

Orient Extrême-Occident [Online], 42 | 2018, Online since 01 December 2020, connection on 04 March 2019. URL : http://journals.openedition.org/extremeorient/1015 ; DOI : 10.4000/extremeorient.1015 


\title{
Disguised Subjectivity in Two Chinese Fictional Dream Narratives of the Qing
}

\author{
Aude Lucas
}

To assert that Chinese oneiric fictional literature is a very large field would be an understatement. Dream deciphering appears as early as the Shang period with mantic interpretation by pyroscapulomancy. ${ }^{1}$ Early literature such as the zhiguai genre takes dreams as a major subject: this serves, for example, as the subject matter of chapter ten in Gan Bao's Soushen ji and about thirty other accounts throughout the book. Over the centuries, Chinese literature maintained the dream narrative as a persistent theme. The durability of this tradition notwithstanding, it would be a mistake to consider the treatment of dreams through the ages in Chinese literature to be a homogenous whole, or even a more or less miscellaneous aggregate of texts that could be put together simply because they are about dreams. As Dimitri Drettas put it so well, it would be misleading to regard dream narratives as a distinct category for literature. ${ }^{2}$ Dreams regularly appeared here and there in literature, but never constituted a coherent whole. They were first and foremost the product of their authors, who themselves belonged to various historical and literary contexts. One of the main difficulties when analyzing numerous literary pieces of work from the angle of dreams is thus to avoid envisioning them as a "speculative continuum," ${ }^{3}$ for each text was shaped by the cultural context of its author. Each author understood specific concepts differently, created an imaginary world of his own, and applied his writing style. He did not necessarily write his text while thinking of how it would fit into a literary category; we must thus consider each text as an independent piece of work, though it might correspond to what we see today as a more or less defined category.

1. Chen 2008: 3.

2. Drettas 2007: 406.

3. Drettas 2007: 406. 
Despite this need for caution, dreams continue to be a topic per se, favored by scholars, as evidenced by the choice of oneirology as a subject for this periodical's current issue. Surely this is because dream narratives, owing to the peculiar features they present in terms of narrativity and their subjective status which allows creativity, are sensed to be a more fertile ground for literary expression than any other texts. Assuming that studying dream narratives is from the start a debatable approach because of the epistemological problems it implies, one might still wish to delineate one's field of study by taking dreams as a subject and to demonstrate how keen indeed Chinese authors were to use oneiric narratives as a privileged vehicle for literary expression.

\section{Subjectivity in dream accounts: a non-linear progression over centuries}

This article deals with fictional dream narratives. As specialists such as Sarah Allen have pointed out ${ }^{4}$ it is hard to determine when Chinese fiction was born, because classical Chinese literature always mingled historical facts, biographies, and hearsay with invented stories. One should therefore bear in mind that although the literature of leisure contained uncanny elements, including dream narratives, it might not have been deemed "fictional" in the way that we understand the term today-meaning that we consider every single element of the story to have been invented by the author. Using the word "fictional" is thus a convenient way for us to distinguish this kind of dream literature from other kinds of dream records - such as those in "books of dreams" (mengshu).

When considering the various fictional dream narratives from early short stories to late Qing novels and tales, one may be struck by the contrast between those that depict a message being delivered to the dreamer without offering any information about the latter's feelings, thoughts or even reactions, and those that on the contrary reveal much about the dreamer's perspective - the former group comprising mostly older texts and the latter covering more recent ones. Dell R. Hales has in this way distinguished on the one hand "simple dreams of disclosure or "divine revelation" as rewards or punishments [that] can often be eliminated from the story without damaging the plot and would, perhaps, even improve the artistic quality of the tale," ${ }^{5}$ and on the other hand other dream narratives that fulfill a key function "as a means of illustrating

\footnotetext{
4. Allen 2014: 4-11.

5. Hales 1976: 76.
} 
justice and matters of retribution" or even stand as "a more complex literary and psychological device." ${ }^{\prime}$ Bearing this distinction in mind is important for this article's main line of inquiry: how some dreams during the Qing reveal more of the dreamer's inner self than it appears at first-in other words, how these dream narratives are more subjective than they look. However, sticking to a binary perception such as that depicted above may only be misleading; it would be a mistake to posit a clear division between earlier dream narratives in which there is no subjectivity and "modern" ones through which the dreamer's inner self is unveiled. The frontier between the two cases, if there were ever one, is much subtler than it may seem and could hardly be delineated within a period, since subjectivity was expressed in varying degrees throughout the centuries.

A definition of subjectivity might here be needed: in literature, we may observe how a text can be subjective when the narrative discloses elements about the inner self of the characters or the narrator. For example, a narrator may involve himself by writing "I" and sharing his own personal comments on the story he tells - in such a case, the text might be very subjective. In contrast, a character-be it the main character of the story or not-might be depicted with very few elements that could inform readers about his thoughts. When almost nothing is said about this character's inner self, it deprives the narrative of subjectivity - the character's depiction may seem shallow, since nothing is clearly revealed about his/her mental condition. As a matter of fact, it took a lot of time before Chinese fictional literature implied such psychological descriptions. My theory is that subjective writing appeared quite late in history - not before late imperial China - and that the Qing was a prominent period with regard to this phenomenon.

This article is an attempt to demonstrate how some dream narratives of the Qing period, though they bear traditional features in their narrative patterns and motifs, also carry a subjective expression of the dreaming character. In other words, how these characters' inner selves are revealed, how the motifs and mechanisms of the narrative may be significant in hidden ways with regard to the character's psyche.

Over the centuries of Chinese interest in dream stories, 17th and 18thcentury authors came at a time when the late Ming craze for oneirology has faded away. This fondness for dreams faded with the collapsing dynasty and the disillusion that followed. However, Qing authors showed an interest in dreams that inherited the Ming fever for oneirology, though with their own discourse applied to it. The whole literary tone of Qing times, which was marked by

6. Hales 1976: 80. 
more disenchantment, searching for explanations, and criticism than during the Ming, thus pervaded oneiric fictions, in ways that were not always easily discernible. As a consequence of this "broken continuity," some fictional dream accounts of the Qing took over conventional oneiric patterns while also conveying a supplementary meaning. What could be newly expressed? Taking a cue from the idea mentioned above that unveiled dreaming subjects appear more frequently in late stories, my thesis is that this supplementary meaning is precisely the subjective exposure. Again, this subjectivity is not necessarily overt - it is more often than not hidden behind classical oneiric devices, so that one has to proceed through analysis to determine how subjectivity is expressed.

Here I shall present two fictional dream accounts as examples of Qing dream narratives whose innovative aspect is a subtle expression of subjectivity. They may be found in two 17th and 18th-century short story collections written in classical Chinese: Liaozhai zhiyi (Liaozhai's Records of the Strange) by $\mathrm{Pu}$ Songling [1640-1715] and Zibuyu (That Which the Master Does Not Speak About) by Yuan Mei [1716-1797]. Both of these dreams reveal things about the dreamers' inner selves, though in indirect fashion.

$\mathrm{Pu}$ Songling and Yuan Mei both wrote stories dealing with the supernatural. The former's writings reached an unmatched level of narrative technique in classical fiction and conveyed a unique esthetic search. Pu's stories may be quite short, but most of them run up to several pages. In contrast, Yuan's accounts are much shorter and his concern was not so much esthetic as moral. Esthetics and morality were not mutually exclusive though-one may consider Pu Songling's vehement criticism to be all the more fierce for having been embedded in fairytale-like stories. These concerns are mainly reflected in dream narratives, in both collections: Pu's stories may constitute very imaginative oneiric escapes while Yuan often used dreams to prove a point. This tendency, however, does not apply to the two examples in this article: Pu's narrative borrows in a very conventional way from the classic motif of a message delivered within a dream and which later proves to be true, whereas Yuan's story tells about a mysterious and poetic dream encounter - a theme which only appears occasionally in his work. The fact that Pu Songling and Yuan Mei should still produce subjective writings which stand apart from their typical treatment of dreams underscores how erratic a process the subjective unveiling was in the history of fictional literature.

Both dreams feature the appearance of common oneiric motifs - a message delivery and a poetic escape with immortals - but analysis discloses in each of them a supplementary level of reading conveyed by subjectivity: both accounts reveal something about the dreamer that actually escapes his own grasp. Because the subjectivity perceived in Yuan's narrative is not as developed as in 
Pu's tale, I shall present these two dreams in reverse chronological order, so as to establish a gradual approach.

\section{A very lonely poetic gathering: all that he dreamt about came in truth from his own self}

"Chu Meifu fucheng shi Yunhui shizhe" ("Sub-prefect Chu Meifu is the Cloud Banner Ambassador") appears in juan fifteen of Zibuyu. It recounts the story of an official who, after having fulfilled his duty to offer sacrifices to the gods of the Five Sacred Mountains and the Four Rivers, spends the night at a post house. In the evening, he witnesses a candle which sparkles in exuberant ways. He then dreams that a group of immortals comes to him and leads him to a hill where they compose poetry. Each immortal declaims a verse and as the group cheerfully laughs, the sparkling candle explodes like a firecracker and the dreamer wakes up with a start. Since many details in this short narrative will matter to our analysis, the story deserves to be quoted in full.

Chu Meifu, ${ }^{7}$ associate Director of the Court of the Imperial Clan, ${ }^{8}$ was able to nourish his vital energy. At the age of seventy, he had the complexion of an infant. During the first lunar month of the gengchen year of the reign of Qianlong, ${ }^{9}$ he was sent on an official mission to offer sacrifices to the gods of the Five Sacred Mountains and the Four Rivers. ${ }^{10} \mathrm{He}$ spent the night at the Solitude ${ }^{11}$ Seekers Post House. In the inn that evening, as he extinguished the candle, it suddenly changed: [its sparkles] became like lotus flowers, like a ruyi stick, ${ }^{12}$ like ganoderma and orchids. Its smoke reached two to three feet high, while wind and smoke whirled

7. Pen name ( $h a o$ ) of Chu Linzhi, whose courtesy name ( $z i$ ) was Lü Chun. He came from Jingxi in Jiangsu and graduated as a doctor in 1739. His biography is to be found in Qingshigao (Draft History of the Qing).

8. Zongcheng is a contraction of zongren fucheng. Officials that worked in the Court of the Imperial Clan were in charge of the imperial genealogy: they kept records of births, marriages and deaths of the imperial family. Hucker 1985: 531.

9. February 1760.

10. Yuedu is a contraction of wuyue "Five Sacred Mountains" and sidu, "Four Rivers." The former are Taishan in Shandong, Huashan in Shaanxi, Hengshan in Hunan, Hengshan in Shanxi, and Songshan in Henan. The latter are Changjiang, Huanghe, Huaihe, and Jihe.

11. As the reader shall see below, the choice of pronunciation dui (instead of dun) for the character 敦 has to do with my interpretation.

12. An ornamental scepter symbolizing power and happiness. 
around. In a hurry, he called for the young servant to watch it, and both of them found it strange, taking care not to move. That evening, he dreamt and saw five or six immortals who beckoned him and took him to some place named "Red Cloud Ridge." They designated Chu as Cloud Banner Ambassador. All the immortals sat in an orderly fashion under the shade of pine trees to compose linking verses. ${ }^{13}$ One of them, who was called The Divine Old Man of the Sea, sang first: "Tonight the lotus candle offered us a ganoderma." It shifted to The Ancestor of the Five Pine Trees who carried on: "In a beautiful gathering immortals chant with mustaches fluttering in the wind." It shifted again to The Blue Lad ${ }^{14}$ of the East who declaimed: "The wind of spring yearns for changing the branches of poplars and willows." Beside him, a female immortal laughed: "Those are verses that the Cloud Banner Ambassador composed when he went across the Ling River. ${ }^{15}$ Why would you intentionally steal them from him?" And together they burst into laughter. All of a sudden, the candle exploded like a firecracker and [Chu Meifu] woke up with a start.

At first sight, Yuan's dream account resembles many other oneiric travels to immortal lands or regions of the dead. Poetic composition is also a common motif in Zibuyu dream narratives. One may notice that during his dream, not a single piece of information is given about Chu Meifu's thoughts or even reaction to the events - a feature of many early dream accounts. Chu thus seems to be a very passive dreamer and the narrative to lack subjective writing. However, analyzing several elements of the story reveals how much the oneiric content is related to Chu himself.

One striking clue is the assertion made by the female immortal that the verses composed by her fellows actually belong to the Cloud Banner Ambassadorthe title Chu Meifu is given by the immortals within his dream. In other words, Chu himself would have composed the verses that the immortals declaim during the poetic game as if they were producing these verses themselves. In this theory, contrary to appearances, the poetic experience is not a collective one, but a lonely one.

This loneliness may be enhanced by the name of the post house in which Chu spends the night. The character 敦 has two possible pinyin readings that

13. A literary game which consisted in poets chanting one verse each, so as to collectively compose a whole poem.

14. This name may refer to the Taoist divinity revered in Shangqing Taoism. It is noticeable that this divinity holds the position of Great Director of Destinies (da siming) at the Five Sacred Mountains (wuyue) that this account mentions. Pregadio 2008: 803.

15. In Liaoning. 
may fit the context: dun and dui. Dun notably refers to sincerity, honesty. Soudun youting would thus stand for "Sincerity Seekers Post House." In his English translation of Yuan's account, Paolo Santangelo uses the reading dun, but he does not translate the name, sticking to "Soudun Post". ${ }^{16}$ However, French translators of the same account-Chang Fu-jui, Jacqueline Chang, and Jean-Pierre Diény-choose to translate the whole name by "Solitude Seekers Post House" ("relais de poste des "Chercheurs de solitude »"), thus considering the pinyin reading for 敦 to be $d u i .{ }^{17} \mathrm{In}$ my opinion, translating 敦 by "solitude" matches better the whole essence of the text-that Chu Meifu, although dreaming about immortal fellows, is all alone.

The oneiric place Chu dreams about is labelled Chiyun gang, ("Red Cloud Ridge"). This name includes the character yun ("cloud"), which is also found in the title Chu Meifu is granted in the dream-Yunhui shizhe ("Cloud Banner Ambassador"). The very place to which his dream takes him is thus somehow related to him.

Considering the verses chanted by the immortals, one may notice that they create a mise en abyme of the story. The first verse- "Tonight the lotus candle offered us a ganoderma"-depicts the curious phenomenon Chu Meifu witnessed in the inn: the candle sparkles taking shape of a ganoderma mushroom. The character zhi could also stand for "iris," but according to this first verse, the candle produced ruizhi, which refers to the ganoderma mushroom. Moreover, ganoderma is a Chinese symbol for longevity which is recognized by Taoists to ensure immortality - an imagery which squares with the immortals of this tale. The second verse - "In a beautiful gathering immortals chant with mustaches fluttering in the wind"-simply describes the poetic gathering itself. As it portrays the friendly gathering which is the frame for poetic composition, this verse appears like a paratext, under Gérard Genette's definition as an element which comes along with the text itself, such as a title, notes, a blurb, etc. ${ }^{18}$ But it is a paratext which at the same time consists of the text itself-the mise en abyme is particularly blatant in this case. This verse in Yuan's account is reminiscent of the "Lanting ji xu" ("Preface to the Pieces Gathered at the Orchid Pavilion"), a calligraphy executed by Wang Xizhi in the 4th century, which recounted in detail a poetic gathering that Wang

16. Yuan 2013: 780.

17. Yuan 2011: 209.

18. Genette distinguishes two aspects of the paratext. The "péritexte" consists in elements that naturally accompany the text -titles, notes, blurbs, prefaces... The "épitexte" includes elements that stand apart from the editorial work-reviews, interviews, various meetings, diaries, and so forth. Genette 1987: 10-11. 
participated in with thirty-six other poets of that time, and which introduced the collection of the poems that were composed on that day. The third and last verse of Yuan's account_- "The wind of spring yearns for changing the branches of poplars and willows" - seems to carry less meaning linked to the events. One may simply notice that spring is the season during which the story occurs.

Through these various details, it becomes apparent that "Chu Meifu fucheng shi Yunhui shizhe" is not as common a dream account as it may seem. Although nothing is explicitly revealed about the dreamer, several elements converge on him and tend to show that the dream carries something about him that is not clearly unveiled. The oneiric content recounts a poetic gathering of immortals, but in truth it is all related to the dreamer. One may sense that Chu is lonelier than his dream suggests, and may even wonder if it is not Chu who has created all the elements of the dream.

Maintaining the very elliptical aspect of classical narrative, the story does not make any transition between the moment when Chu and the young servant observe the candle and when Chu begins dreaming. The presence of the servant seems to be very practical: adding a second witness would tend to ensure the reality of what Chu saw. But as the narrative does not tell about any conversation between them nor the moment when Chu sends the servant back, this guarantee for reality is counterbalanced. Moreover, the candle's marvels are obviously related to the dream: the latter ends when the former explodes. This blurs the frontier between reality and dream - was the servant truly there? When did the dream actually begin?

That the reader should be granted no glimpse inside Chu's thoughts, even after the dream is ended, contributes to cloistering the character into a dimension that seems to derive from himself, but without letting the reader know if the dream was indeed modeled upon Chu's inwardness. Although the dream itself as well as the curious sparkling of the candle are quite unaccountable, Chu is portrayed as an uncommon character who holds a privileged position towards magical disclosures. The fact that he is an official - a social status which no immortal would wish to occupy - but still has the complexion of an infant at age seventy (just like an immortal would) makes him a singular character to whom extraordinary things such as the candle phenomenon unsurprisingly happen. It may be noted that this imagery of forms, especially flowery ones, arising from a stick-shaped object is similar to what is found in Wang Renyu's "Meng bitou shenghua" ("Dreaming of the brush tip gushing forth flowers") from Kaiyuan Tianbao yishi (Remains of Kaiyuan and Tianbao Eras). This Five Dynasties [907-960] account, which became a proverb referring to great literary skills, briefly recounts that in his early years, the famous Tang poet Li 
Taibai [701-762] dreamt that the tip of the brush he used gushed forth flowers, the dream being a hint as to his future literary career. ${ }^{19}$ Just as Li's magical brush symbolizes literary talent, the sparkling candle in Yuan's account is linked to literary creation, as evidenced by the poetic gathering or even the dream itself - be it Yuan's creation of a text as an author or Chu's creation of an oneiric adventure as a fictional dreamer.

Even though it remains uncertain whether the dream occurs because of an external entity or because of Chu himself, it appears quite sure that at least something about the dreamer runs throughout the oneiric experience, and the absence of reaction on the part of Chu makes it seem as though this personal content of the dream escapes him - as if, not being even aware of this personal implication, he fails to understand that the dream's content is about himself. However, although it appears that this content indicates something about Chu being a lonely character, this part of his subjectivity remains unclear. The precise reason why he dreams is not given - though we may wonder here if dreaming without any specific reason might be, in Chinese fictional literature, a feature of more innovative dream narratives. The analysis of my next example should provide more precise details about how the subjectivity of the character is unveiled.

\section{What had not been fixed into his psyche came back to him: a psychotic dream}

The second narrative that stands here as an example of the creativeness of Qing dream accounts comes from Liaozhai zhiyi tale "Shi Qingxu". ${ }^{20}$ In contrast to Yuan's account, the dream narrative itself is very short compared to the long story it is embedded in. Despite its brevity, this dream is particularly revealing of the dreamer's subjectivity - though as in the first example, this is not overt and may be established only through analysis. Moreover, it would be quite impossible to comprehend how revealing of subjectivity this dream is without proceeding through a close review of the whole tale.

19. "In his youth, Li Taibai dreamt that the tip of the brush he used gushed forth flowers. Later, his talent was rich and extraordinary, and his name spread under heaven." Wang 2006: 38 .

20. It is the 450th tale in the Shanghai guji edition, which is believed by specialists to be the edition that best follows the order of the tales that was given by $\mathrm{Pu}$ Songling. $\mathrm{Pu}$ 1978: 1575-1579. 
As in "Chu Meifu fucheng shi Yunhui shizhe," the dream in "Shi Qingxu" covertly hints at something about the dreamer, without him knowing anything about it. The story is about a man named Xing, who is fond of rocks. Namely he is a shichi ${ }^{21}$ ("crazy about rocks"). He possesses a collection of stones and is described as not hesitating to pay a huge price when he encounters a precious mineral. One day, as he is fishing, he discovers by chance in the water a magnificent rock that presents exquisite natural carvings; it is such an amazing stone that Xing can sense it is highly unusual and much to be treasured. He displays this inestimable rock in his home, without realizing that it could stir the envy of a powerful man, who takes the stone away outright. From then on starts a cyclic series of scenarios in which the mineral is stolen from Xing, who each time succeeds in retrieving it. From petty thieves to high-ranking officials, many covet the stone and find ways to plunder it. But Xing repeatedly recovers his treasure. The tale ends up with the rock falling on the floor and getting smashed; Xing's son puts the pieces back in his father's grave-as the stone had been stolen from his tomb.

Judith Zeitlin noticed that once Xing discovers this rock, the rest of his collection is never mentioned again. ${ }^{22}$ The fact that this stone overshadows all the others clearly makes it now the utmost object of interest for Xing. The rock is strikingly unique and of highest value for him because it encompasses all that he could ever find in other stones. Xing develops such an affection for the stone, and repeatedly puts so much effort in seeking to be reunited with it, that it appears as though he considers the mineral to be a partner. One element which reveals how deeply he cares for the stone and how fearful he is about losing it is the incense he burns each time he gets the rock out. Since he knows many people may covet his mineral, Xing wraps it in a piece of brocade and keeps it in a chest. He seldom gets the rock out, and when he does, he first burns rare incense. The fact that Xing chooses to burn this rare incense on multiple occasions eventually makes it a ritual. Each time he is about to seek pleasure in admiring the stone, he feels anxious about it being stolen again. The incense ritual aims at diminishing his fear, gaining control over his owning the rock.

Xing's ownership of the stone, however, is not something that is settled when he discovers it in the river, but rather something that he acquires afterwards. Having already lost and retrieved the rock once, Xing sees an old man coming

21. The term shichi is never employed in Pu Songling's tale, and only the commentator Feng Zhenluan explicitly deems Xing a shichi in this comment: "one may call this gentleman a man crazy/foolish about rocks." Pu 1978: 1575.

22. Zeitlin 1993: 87. 
to his home. The visitor declares that the mineral belongs to his own family. Xing claims otherwise, but the old man proves to possess knowledge about the rock that Xing does not have: he declares the largest cavity of the stone to be engraved with five characters-qingxu tianshi gong ("Offered by Pure Emptiness Celestial Rock") - and the rock is indeed engraved in such a place with these characters. It is interesting to notice that when the old man shows these carved characters and the number of holes to Xing, they are the signifiers of his not being the owner of the stone. But in highlighting these signifiers, the old man actually alters them and turns them into the mark of Xing's ownership over the stone: later in the story, Xing uses this knowledge of the existing carved characters and the number of cavities as signifiers of his ownership of the rock and thus appears justified in retrieving his property after it has been stolen from him again. The old man explains to Xing that the rock "appeared too early" (qi chu ye zao) and that its "evil force" (mojie) has not been evacuated yet. For that reason, the old man should keep the rock for three years before giving it back to Xing. However, one way for Xing to avoid this separation from the stone would be to agree to diminish his own life by three years. Of course, Xing immediately accepts the deal ${ }^{23}$ and the old man closes three of the rock's hollows. The stone originally had ninety-two small cavities; closing three of them brings the number of holes to eighty-nine. It is at eighty-nine years of age that Xing eventually dies. The rock's hollows are thus the signifiers of Xing's life, a fact that reinforces the idea that the stone is closely related to Xing.

Beside this strong relationship between Xing and the rock, the interpretation I would offer of this tale is that its originality lies not so much in the uncanniness of the mineral but rather in what one may guess about Xing's mental state. In spite of the relationship that binds Xing and the rock, my hypothesis is that he is a very lonely character, like Chu in the previous example but on another level, and one who seems to act with psychotic tendencies.

I need here to explain my theoretical orientation and the methodological tools used in the analysis below: it is from a psychoanalytical perspective that I would like to interpret Xing's subjectivity. Psychoanalysis is a 20th-century discipline, but when used for literary analysis, it is not so much a subject area as a structural tool that may be used regardless of cultural background, just as linguistics may be applied to any foreign language. In my study of Chinese

23. It is at this moment that the commentator Feng Zhenluan deems Xing a shichi ("crazy/ foolish about rocks"). It is interesting to see that he does so only when Xing gives up a part of his life, which could mean that someone can be said foolish or crazy about something when he is ready to sacrifice some years of his own life for it. 
dream narratives, I have noticed that researchers more often than not stick to a humanistic approach and typically explain a literary dream by the character's emotional state. However, it seems to me that such interpretations are not sufficient, and that one needs to adopt a more comprehensive approach.

The use of psychoanalysis to interpret dream narratives is not the only tool available. One of its inconveniences, for instance, is that it disregards cultural specificities, while cultural background does matter in the understanding of dream contents and the narration of dreams. Nevertheless, a structural tool such as psychoanalysis may bring to light universal mechanisms of psyche. I think that phenomenological and structural approaches may complement one another, and that it is only in combining the two that one may fully understand complex phenomena such as dream narratives-which both belong to one specific cultural area and share universal features.

The overall impression that strikes the reader of the tale is that of a continual anguish caused by the ill-treatment that comes from everywhere around Xing. At the same time, the whole story revolves around the relationship between Xing and the stone, in an "overinvestment" in this relationship. One who is familiar with psychology might compare this to a case of psychosis: the tale could be read as if Xing suffered from mental disorders but did not know about it - and we, as readers, are confined in his delirium, because we are not granted the exterior look that could offer us critical distance. Such is the basic feature of a psychotic patient: he/she does not know about his/her mental disorder-in contrast to a neurotic person who is aware of reality but does not want to hear about it. Freud depicted psychosis as a mental state in which the ego, because reality is unbearable to him/her, constructs a new world that is both interior and exterior (which explains why the patient thinks he talks to other people while in fact he talks to himself). This new world is constructed according to the desires of the "it"- - basic desires that are not regulated by censorship. ${ }^{24}$ In short, the psychotic person loses the sense of reality, and suffers from hallucinations and dementia. In the case of "Shi Qingxu" it is possible to interpret Xing's passionate relationship to the rock as a one-person delirium: only late in the story does the reader learn that Xing actually has a wife and son, and even though these characters appear, they are never given the opportunity to speak and express what they think of Xing's obsession for the stone.

To come back to the rock itself, one cannot miss that it is a very important signifier for Xing, but why he is so crazy about this rock-and stones in general-remains mysterious. Contrary to the main character of another

24. Freud 2002 [1973]: 284. 
Liaozhai zhiyi tale, "Shuchi" ("Bookworm"), ${ }^{25}$ his passion for rocks is not given any explanation. In "Shuchi" the main character's mania for books is clearly explained within the introductory lines of the tale by the fact that he is the descendant of a whole line of righteous officials and that he inherited his library from his own father. These origins justify his irrational will to preserve his books, in spite of both his financial problems and criticism from a supernatural young woman who accuses him of failing his examinations precisely because he reads too much. But in the case of Xing, there is not a single explanation for the origins of his passion for stones. The stone thus stands for a signifier that has no "signified," in the Saussurian sense; it is an empty signifier that revolves around Xing-it is repeatedly stolen and retrieved. In Lacan's depiction of psychotic language, signifiers are deemed important by the patient, but deprived of any "signified" since the patient does not know why the signifier is so important to him/her. Psychotic patients may pay a lot of attention to signifiers around them, to any kind of object, to the point of sounding obsessional-they might repeat over and over again the word to designate this signifier-but they are incapable of explaining what kind of feelings they have regarding this object, much less why they feel this way. It seems to me that this tale functions on the same grounds: the text keeps repeating how fond Xing is of rocks, but never explains why, so much so this empty motif runs idle.

Assuming that, as a character, Xing illustrates psychotic disorderswhich is different from envisioning Xing as psychotic person, for he is just a character invented by his author - we may now investigate more deeply the structural theories of psychosis. Jacques Lacan [1901-1981], who devoted his doctoral thesis and much of his life's research to psychosis, conceived this mental disorder as a phenomenon which takes root when an infant should first enter the Oedipal stage, but fails at doing so. In Lacanian theory, when children are born they feel themselves to be in a fusional relationship with their mother. The mother does not need to make herself known to the infant, who considers her the utmost object of its desire-it is like in an incestuous relationship to her-and after being separated from her during the Oedipal stage (I will come back to this), the grown person he/she will become will always try to recover this utmost object of desire, through disguised ways - the person will displace his desire onto other objects.

In contrast to what happens with the mother, it does not come naturally to the infant that the Father is... a Father. "Father" here does not necessarily indicate a male person, but rather a function: it might be any entity, human or

25. Pu 1978: 1453-1458. 
institutional - even society itself - that plays a fatherly role. What role is that? The "Father" is an entity that subjugates the mother to his law - the infant realizes the mother does not obey his/her desire, because she is subjected to the law of another-one which notably forbids incest between the mother and the infant. In this process, the infant understands that there is an "Other" (the "Father"). He/she symbolizes the "Father" as a barrier, a prohibition of his/ her desire for the mother. The "Father," in Lacanian theory, is thus the first of all signifiers of language; Lacan called it "Nom-du-Père" ("Name-of-theFather").

Sometimes, however, it happens that the mother fails at transmitting this signifier to the infant-she does not make him/her understand that the fusional relationship with her is forbidden by the law of an "Other". Lacan said that in such a case, the "Name-of-the-Father" is "forclos" ("foreclosed"). What may result from such a failure? The infant does not learn that he/she should not feel so close to the object of his/her desire. He/she does not symbolize the "Other," which means that he/she can imagine that there is an "Other" but does not truly believe that it is someone else; in other words, a psychotic patient might talk to an imaginary "Other" but in reality he/she talks to him/herself.

Lacan identified three orders of the psyche: the real, the symbolic and the imaginary. The real corresponds to facts as they are; it cannot be expressed with words, and it must be understood that our "reality" is not the real. Our "reality" is also perceived through the symbolic and the imaginary. The symbolic is the meaning of a signifier that we share with others: for example, a dove may connote peace. The imaginary is how I personally perceive the signifier, according to my own experience: the dove might remind me of my parent's house, because doves used to live there. In other words, one's psyche is made of three orders that are interdependent. Lacan represented the three-layered mind by the Borromean knot, a figure made of three rings whose distinctive characteristic is that if one ring is missing, the other two are detached from one another.

\section{Figure 1}
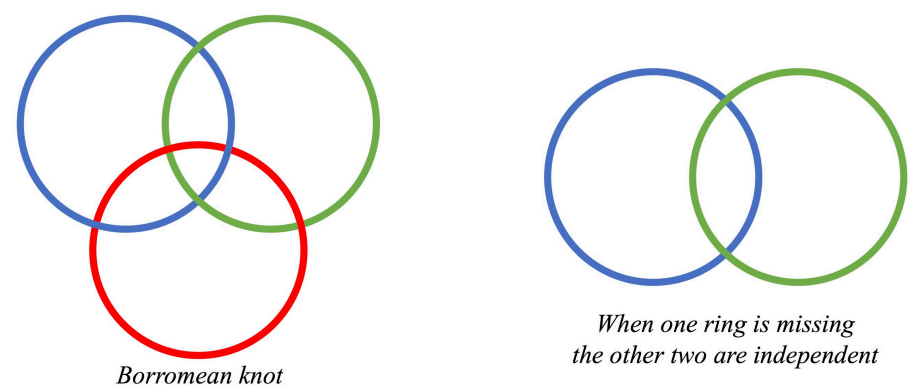
As I mentioned above, during one's lifetime, a person always seeks to retrieve the original object of his/her desire (the mother) by feeling multiple desires for other objects - concrete ones such as cars and jewels or abstract ones such as power or fame. Such objects are called "fantasies." A psychotic person does the same, but with an overinvestment-because he/she did not learn to refrain from seeking the utmost object of desire. Overinvesting in a fantasy may lead to cases such as Xing's craziness for the rock.

Because Xing is after all just a literary character, it would be laughable to think that we might go back to his infancy to find the reason why he did not create a symbolic order for himself. There is simply no reason for his mental state in the tale except for the author's wish to depict him in such a way. We may, however, observe that his behavior matches the symptoms of a psychotic person, and so the theoretical origins of psychosis I have laid out may help us to interpret Xing's story.

That Xing is a character who lacks the symbolic order of psyche is perceivable in the way he treats the rock. He clearly does not share with other people the commonly accepted view of stones: to him, they are not insignificant mute objects without feelings - "wood and stone have no feelings" (mushi wuqing) being one Chinese idiom. ${ }^{26}$ On the contrary, he treats his rock as if it were a person-we shall see that this personification is completed in Xing's dream. In his mind, there stands no coercive force that could regulate his obsession for the rock - no "Father" to obstruct this fusional relationship. As explained above, the rock might be a substitutive object appropriated by Xing to retrieve the original object of his desire-which is unknown but can be visualized as a metaphoric "mother." The stone would thus be Xing's fantasy. But without the symbolic order, Xing is left alone with his fantasy, talking to himself in his own world, in the Freudian sense-the rock might even be a part of himself. The way the rock seems to be related to Xing tends to confirm such an interpretation: the number of its holes matches Xing's age. Moreover, Xing's encounter with the rock's owner, the old man, has no exterior witness. The visitor does not tell Xing his name. He also explains that the rock can choose its own master $(z i z e z h u)$ and that it should be Xing because "the treasures under Heaven should be with those who cherish them" (tianxia zhi bao dang yu xi'ai zhi ren). ${ }^{27}$ All these elements participate in the hypothesis that the rock's supernatural powers and free will could actually be the products of Xing's imagination.

26. Yu 1997: 120.

27. Pu 1978: 1576. 
In Lacanian theory, when the "Father" is not symbolized in the psyche a curious phenomenon may result: it can come back to the subject from outside and into the real, as a hallucination. ${ }^{28}$ This resembles a delirium: an "uncontrolled irruption of the figural into discourse." ${ }^{29}$ In "Shi Qingxu" there are two elements that illustrate how non-symbolized signifiers come back to Xing into the real. First of all, the Name-of-the-Father - the fatherly functionthat we may assume Xing did not symbolize (he did not acknowledge the presence of an "Other") and which is not present to prevent him from an overinvested relationship with the rock, comes back to him "for real" as the old man who claims that the stone belongs to his family. This old man appears as an impediment to Xing's passion for the rock. Metaphorically, he represents a barrier to their fusional relationship. In theoretical terms, he could be the "Father" that forbids the incest-note that the relationship between a man and a stone, while it cannot be deemed "incestuous," may be regarded as a nonnatural one. Xing, however, dismisses the threat by making a sacrifice - three years of his life - that binds him even closer to the rock. The old man thus simply makes a temporary appearance, as though in the hallucinatory mode that usually characterizes the manifestations of gods (shen) - which Xing in fact believes the old man to be.

The second element that illustrates how a non-symbolized signifier comes back to the subject into the real is to be found in Xing's dream. When Xing is deprived the rock for the third time, by a minister who sends him to jail with the specific purpose of improperly acquiring the magnificent stone, he is so desperate that he contemplates killing himself.

At night, he dreamt of a man coming to him who called himself "Shi Qingxu." He warned Xing against being sad: "This exceptional separation from you is to last for slightly more than a year. Next year, at the dawn of the twentieth day of the eighth month, go to the Haidai Door, where you may redeem [it] for two strings of money.

The name of the oneiric character reminds one of the characters engraved on the rock, and it appears quite convincing that the man in the dream is the embodiment of the mineral. ${ }^{30}$ Shi Qingxu as an anthropomorphized character

28. Lacan 1981: 57.

29. Bellemin-Noël 1996: 81.

30. Judith Zeitlin remarks that the fact that the character shi ("rock") is no longer placed at the end, as in the carving, but at the beginning of the name Shi Qingxu, "assum[ing] the Chinese position of a surname... suggests a subtle anthropomorphization." Zeitlin 1993: 83. 
stands for a "literal realization of metaphoric language." 31 To Xing, the stone is the metaphor of an ideal partner. In his dream, the signifier shi is given another signified than "stone as a mineral inanimate object": shi becomes a person, the literality of the partner metaphor. The character shi becomes the signifier of the signified "person whose name is Shi," as a patronym. The same logic goes for the two characters qingxu: these are the grammatical attributes of noun shi in qingxu tianshi gong, the phrase engraved on the rock. In his dream, Xing turns them into a hyper-readable given name. In other words, the figural representation of the rock as Xing's partner becomes real. If this phenomenon were observed in a clinical context it would be described as a psychotic neologism, which is not necessarily the invention of a new word, but the use of a preexisting signifier with another semantic use. Freud wrote that in such a case "the word becomes the thing itself." ${ }^{32}$ In Xing's mind, the signifier shi is not well fixed and can mean everything as much as nothing. It is like the words mentioned above that psychotic patients keep repeating without knowing what it means to them. When someone asks them to explain the word, they would answer: "But you know it." ${ }^{33}$ In the end, the signifier signifies the patient's own inability to fix meaning. Simultaneously, the signifier can be attached to several semantic fields: while it originally designated a mineral object, it now refers to a person. The fact that the rock is not symbolized in Xing's mind - the character does not share with others the usual signified attached to the shi as a signifier-leads to a coming back of the signifier (the rock) into the real: a dream in which Shi Qingxu is a partner who comes "from the outside" to search for Xing. Psychoanalyst Philippe Julien writes that when someone suffers from delirium, voices of his own interior discourses seem to come from someone else, who takes the initiative to speak. ${ }^{34}$ The example of Xing's dream is quite illustrative of this statement.

Not all patients with psychotic tendencies are actually psychotic. In his 1975-1976 seminar entitled Le Sinthome, Lacan considered James Joyce's work, which he deemed to be characteristic of the psychotic tendency. ${ }^{35}$ In Joyce's stories, the father is generally an absent figure. Characters in his novels usually lack the fatherly function that could enable them to establish

31. Judith Zeitlin identifies it as "one of Pu Songling's most common mechanisms for generating fantasy," through which he "restores the shock of immediacy to a dead metaphor, reinvesting language itself with a new strangeness." Zeitlin 1993: 145.

32. Menard 2008: 10.

33. Stevens 2001 .

34. Julien 2000: 51.

35. Lacan 2005. 
the presence of a "law," a powerful "Other" that would regulate the urges of their desire. But Lacan interpreted Joyce's writings as a way to compensate for this absence: Joyce's novels are full of puns, quips, and neologisms. As he created so many of these, he bent language to his own will, to name things as he perceived them. In doing so, he became famous, he acquired a name through literature. For Lacan, while Joyce lacked the Name-of-the-Father, he made himself "Père-du-Nom" (Father-of-the-Name). In his theory, Joyce's work upon language is an offsetting process, a "suppletion" that Lacan named "sinthome." He illustrated such a process by adding a fourth ring to the Borromean knot. This last ring functions as a tie: if one of the rings - the one that stands for the symbolic, for instance - is missing, the remaining two rings are still attached, and the patient's mind does not go crazy.

Figure 2
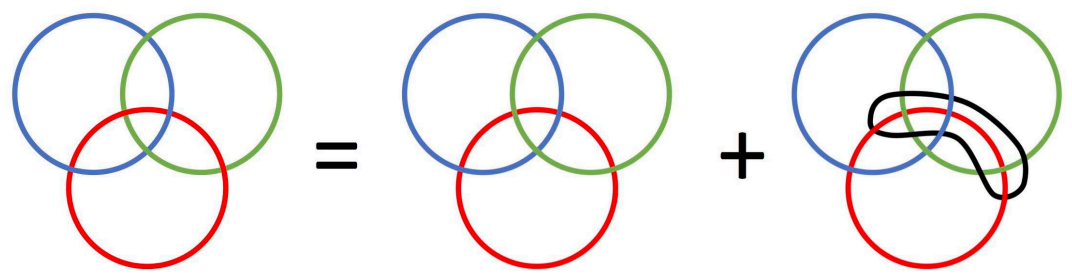

The Borromean link of the knot is made possible by the sinthome

In "Shi Qingxu," what seems to be a creative literary motif is precisely that the metaphorical ideal partner comes back to Xing as a real person-that the figural should make an irruption into discourse. Judith Zeitlin remarks that this is "one of Pu Songling's most common mechanisms for generating fantasy." 36 The neologism "Shi Qingxu" as a person thus belongs to a literary motif that $\mathrm{Pu}$ often uses, and for which he is known. In other words, this motif is the "sinthome" of Liaozhai zhiyi, and it hints as well at the symptoms of the psychotic tendency in "Shi Qingxu."

At the same time, though he exhibits psychotic characteristics, Xing does not become mad. He builds something that enables him to exist as a psychologically healthy subject in spite of his loss of reality. Although it is within his dream that the delirium with words takes place, it is precisely the function of this dream to place Xing in an acceptable position. In a classical manner, the narrative

36. Cf. footnote 31 . 
proves Xing's dream to be true. Shi Qingxu reassures Xing: one year later, on a given day, he must go to a given place where he can buy his stone back for two strings of coins. The oneiric message later proves to be accurate, as Xing retrieves his rock at the place and time Shi Qingxu augured. That the oneiric prediction should later be confirmed by objective facts is a very ancient feature of Chinese dream tradition. ${ }^{37}$ Countless dream accounts, in Liaozhai zhiyi as well as in many other Qing oneiric narratives, still use this ancient narrative technique with more or less creative variations. By presenting this classical feature, Xing's dream follows a reassuring, recognized pattern. The dream thus has something to do with commonly established signifiers. It can be interpreted as a way in which psychosis is countered by Xing's participation in a tradition with well-known codes. By having this traditional oneiric pattern on his side, Xing controls his hectic life and controls events.

That "Shi Qingxu" echoes the symptoms of psychosis may be significant regarding the potential modernity of the tale. Modernity is a vast concept which cannot be treated in a short article such as this one. Let us simply observe what French literary critic Roger Bozzetto wrote about psychotic characteristics in literature.

As readers, we do not have the possibility of adopting a critical perspective. We are trapped in the narrative and experience the effects of psychosis along with the character, as with Xing - this being the condition under which readers perceive the fantastic. 38 According to Bozzetto, it is due to this resemblance with a psychotic universe that the fantastic may be deemed modern. ${ }^{39}$ Along with this impossibility of finding meaning anywhere else than in the text itself, Bozzetto identifies the modernity of the fantastic as the failure to link what is anguishing with something that would have previously been symbolized. In the classical fantastic, the anguish comes from something symbolically identified, but which, out of fear, is not named ("innommé"). In the modern fantastic, the anguish arises from something foreclosed - that cannot be named ("innommable"). In "Shi Qingxu," the reason for the anguish-why Xing is so obsessed with this rock and fearful of its loss-remains unidentified, as I explained above, while the unease it creates lingers and finds no answer in spite of the reader's hope for some explanation. The character is ignorant of

37. "Corroborating subjective events with what were regarded as objective forms of evidence remained a prominent technique of Chinese dream interpretation, and can be seen as having an early origin [...]." Chen 2008: 3 .

38. Terramorsi 1994: 119.

39. Bozzetto 1980. 
this answer while he embodies it at the same time-just as a psychotic person does. ${ }^{40}$

\section{Conclusion}

Both accounts presented in this article illustrate the subtle way in which fictional dream narratives could be written in more subjective ways during the Qing. While they adopt very classical oneirological narrative patterns, these dream accounts disclose much more than they appear to about the dreaming subject. Although this subject does not react within his dream-he does not speak or complete any action, nor are any of his thoughts indicated-analysis has revealed that the oneiric experience is all about something in him that he himself cannot grasp.

"Chu Meifu fucheng shi Yunhui shizhe" has proven to conceal many elements that allude to the dreamer himself-especially the content of the verses declaimed during the oneiric poetic gathering. An examination of proper names in the story - the title Chu is given, the name of the inn where he spends the night-reinforces the impression of an oneiric content centered around the dreamer. Even though the dream takes Chu to a gathering of immortals, the feeling that emerges is one of loneliness. For example, it is acknowledged that the verses chanted by the immortals were in reality composed by Chu himself. In this elliptical account, what causes the dream remains unexplained. It makes the reason why the dream content should come back to the subject under disguised forms all the more enigmatic. The richness of this dream narrative lies in the fact that while it resembles a poetic experience that involves collective creation, it actually leans toward a more personal creative experience.

The analysis of "Shi Qingxu" reveals an even more compelling subjective development of its character, Xing, who presents symptoms that are analogous to a case of psychosis. Xing overinvests himself in a fusional relationship with a rock, which is an "empty" signifier: even though Xing risks his life for this object, the reader never learns why he cares so much for it. Just like a psychotic patient, Xing seems to lack what Lacan called the Name-of-the-Father, a force that regulates the relationship between a subject and the object of his desire. Not having accepted that there is this "Other," this interfering entity, the subject does not create a symbolic order for him/herself, along with the imaginary and the real, in Lacanian terminology. He thus does not share with others their common meaning-just like Xing does not share the commonly

40. Bozzetto 1992: 144. 
accepted fact that a rock is an inanimate object. One symptom of psychosis that Lacan described, and which appears in the tale, is the hallucinatory return of the regulating entity into the real: Xing encountering an old man who threatens to take the rock away, and the rock becoming a person in his dream, both illustrate this psychotic phenomenon. At the same time, that the stone as an ideal partner should appear in the dream as a human being stands among $\mathrm{Pu}$ Songling's favorite literary motifs. As such, this irruption of the figural into discourse in Liaozhai zhiyi is a "sinthome" - a Lacanian term to depict the way some authors such as James Joyce bend language to their will, through puns and neologisms, and thus compensate for the fact that the meaning of words is not well fixed in the symbolic order-that they do not share with others the usual meaning of words.

Perceiving Xing's psychotic tendency does not mean, of course, that $\mathrm{Pu}$ Songling was aware of these specific features he gave to his character. This all remains a literary interpretation. However, showing that this character's features match the mental state of psychosis demonstrates Pu's insight into human nature.

Early and mid-Qing fictional dream narratives are fascinating because even without having been written by authors who, like those in the 20th century, had received some knowledge of European literature and psychoanalysis, they were still produced by writers who searched for renewed ways of narrating a dream. The Chinese oneirological tradition being ancient and vast, authors constantly used, modified, and adapted an already abundant literature-while also being influenced by other forms of literature, such as the performing arts. Through this continual reworking of literary materials, authors started to write about the inner self of their characters - though not suddenly nor through a progressive evolution. 17th and 18th-century dream accounts are emblematic of this emerging depiction of mental inwardness and constitute a very subtle combination of narrative tradition and subjective expression. On rare occasions - such as Lin Daiyu's dream, in chapter 82 of Honglou meng fictional dream narratives not only revealed a lot about the character's inner self, but also escaped from established narrative patterns: the story is no longer about a brief encounter between a god and the dreamer, as was common in classical tales, but shows complexity in terms of the spatiotemporal setting and characters involved-who might be imaginary projections of real characters, just like in real dreams as cognitive experiences. Furthermore, while classical narrative patterns would more often than not imply that the dreamer should use the knowledge he/she acquired in his/her dream to change things in his/ her waking life, these few dream narratives did not necessarily require any "consequence" of the dream in daily life. Conversely, a search for ancient 
dream motifs in such renewed narratives may also be instructive-Daiyu's dream does also present later in the novel, in modernized ways, that very ancient element which is the proof of the veracity of the dream. This two-way envisioning is necessary to comprehend how a theme as ancient as the dream was continually renewed with much interest by Chinese authors up until the 20th century.

\section{BIBLIOGRAPHY}

ALLEN Sarah M. (2014). Shifting Stories: History, Gossip, and Lore in Narratives from Tang Dynasty China. Cambridge (Mass.), Harvard University Asia Center.

BELlEMIN-NoËL Jean (1996). Vers l'inconscient du texte. Paris, Presses Universitaires de France.

BozZETTO Roger (1992). L'Obscur objet d'un savoir. Fantastique et science-fiction : deux littératures de l'imaginaire. Aix-en-Provence, Université de Provence.

BOZZETTO Roger (1980). "Une approche des textes produisant des effets de fantastique moderne." Europe, 611. Retrieved 14 April 2016 from [http://www.noosfere.org/ icarus/articles/article.asp?numarticle=401].

Brown Carolyn T. (ed.) (1988). Psycho-Sinology: The Universe of Dreams in Chinese Culture. Washington, Woodrow Wilson International Center for Scholars, University Press of America.

CHEN Shiyuan (2008). Wandering Spirits: Chen Shiyuan's Encyclopedia of Dreams, edited and translated by Richard STRASSBERG. Berkeley, University of California Press.

DoR Joël (2002). Introduction à la lecture de Lacan. Paris, Denoël.

DRETTAS Dimitri (2007). "Le rêve mis en ordre : les traités onirologiques des Ming à l'épreuve des traditions divinatoire, médicale et religieuse du rêve en Chine," doctoral dissertation. Paris, École Pratique des Hautes Études.

FREUD Sigmund (2002 [1973]). Névrose, psychose et perversion, edited by Jean LAPLANCHE. Paris, Presses Universitaires de France.

GenetTe Gérard (1987). Seuils. Paris, Le Seuil.

Hales Dell R. (1976). "Dreams and the Daemonic in Traditional Chinese Short Stories." Critical Essays on Chinese Literature. Hong Kong, Chinese University of Hong Kong: 71-88.

HuCKer Charles O. (1985). A Dictionary of Official Titles in Imperial China. Taipei, Southern Materials Center Inc.

Huntington Rania (2017). « Rêves des morts : cas tirés des annales de la famille Yu de Deqing ». In Fantômes dans l'Extrême-Orient d'hier et d'aujourd'hui, vol. 1, translated by Vincent DURAND-DASTÈs. Paris, Presses de l'Inalco: 171-201. 
Julien Philippe (2000). Psychose, Perversion, Névrose. La lecture de Jacques Lacan. Ramonville Saint-Agne, Érès.

LACAN Jacques (1981). Le Séminaire de Jacques Lacan, Livre III. Les Psychoses, edited by Jacques-Alain MiLLER. Paris, Le Seuil.

LACAN Jacques (2005). Le Séminaire de Jacques Lacan, Livre XXIII. Le sinthome, edited by Jacques-Alain MILLER. Paris, Le Seuil.

LANSELLE Rainier (2012). "La marque du père." Extrême-Orient Extrême-Occident, hors-série: 83-112.

LAUFER Berthold (1931). "Inspirational Dreams in Eastern Asia." The Journal of American Folklore, 44(172): 208-216.

LI Wai-Yee (1999). " Dreams of Interpretation in Early Chinese Historical and Philosophical Writings ». In Schulman David and Guy Stroumsa, Dream Cultures: Explorations in the Comparative History of Dreaming. Oxford, Oxford University Press: 17-42.

LIU Wenying 劉文英, CAO Tianyu 曹田玉 (2003). Meng yu Zhongguo wenhua 夢與中 國文化. Pékin, Renmin chubanshe.

MENARD Augustin (2008). Voyage au pays des psychoses. Ce que nous enseignent les psychotiques et leurs inventions. Nîmes, Champ social.

ONG Roberto (1981). "The Interpretation of Dreams in Ancient China," Ph.D. diss. Vancouver, University of British Columbia.

PREGADIO Fabrizio (ed.) (2008). The Encyclopedia of Taoism. London, Routledge.

PU Songling 蒲松齡 (1978). Liaozhai zhiyi huijiao huizhu huipin ben 聊齋誌異 [Notes of the Strange by Liaozhai. An edition gathering various lessons, notes and commentaries], edited by ZHANG Youhe. Shanghai, Shanghai guji chubanshe.

SOYMIE Michel (1959). "Les songes et leur interprétation en Chine." In Les Songes et leur interprétation. Paris, Le Seuil : 275-305.

STEVEns Alexandre (2001). « Désarroi et inventions dans la psychose ». Pont Freudien. Retrieved 13 April 2018 from [http://pontfreudien.org/content/alexandre-stevensdésarroi-et-inventions-dans-la-psychose].

TERRAMORSI Bernard (1994). Le Fantastique dans les nouvelles de Julio Cortázar : rites, jeux et passages. Paris, L'Harmattan.

WANG Renyu 王仁裕 (2006). Kaiyuan Tianbao yishi 開元天寶遺事 [Legacies of Kaiyuan and Tianbao Eras] An Lushan shiji [High Deeds of An Lushan], edited by YAO Runeng. Beijing, Zhonghua shuju.

Wu Yenna (1996). "Outlaws' Dreams of Power and Position in Shuihu zhuan.” Chinese Literature: Essays, Articles, Reviews, 18: 45-67.

YU Anthony C. (1997). Rereading the Stone: Desire and the Making of Fiction in Dream of the Red Chamber. Princeton, Princeton University Press.

YUAN Mei (2013). Zibuyu, "What The Master Would Not Discuss", according to Yuan Mei (1716-1798): A Collection of Supernatural Stories, translated by Paolo SANTANGELO. Leiden, Brill.

YUAN Mei (2011). Ce dont le maître ne parlait pas : le merveilleux onirique [Zibuyu], translated by CHANG Fu-jui, CHANG Jacqueline, and Jean-Pierre DIENY. Paris, Gallimard. 
Aude Lucas

ZeITLIN Judith T. (1993). Historian of the Strange: Pu Songling and the Chinese Classical Tale. Stanford, Stanford University Press.

\section{GLOSSARY}

Changjiang 長江

Chiyun gang 赤雲岡

Chu Linzhi 信麟趾

Chu Meifu fucheng shi Yunhui shizhe 儲梅夫府丞是雲麾使者 da siming 大司命

Feng Zhenluan 馮鎮巒

Gan Bao 干寶

hao 號

Hengshan 衡山

Honglou meng 紅樓夢

Huaihe 淮河

Huanghe 黃河

Huashan 華山

Jihe 濟河

Jingxi 荆溪

Lanting ji xu 蘭亭集序

Li Taibai 李太白

Liaozhai zizhi 聊齋自誌

Lü Chun 履醇

Meng bitou shenghua 夢筆頭生花

mengshu 夢書

mojie 魔劫

mushi wuqing 木石無情

qi chu ye zao 其出也早

Qingshigao 清史稿

qingxu 清虛

qingxu tianshi gong 清虛天石供

ruizhi 瑞芝

shen 神

shi 石

Shi Qingxu 石清虛

shichi 石癡

Shuchi 書癡

$s i d u$ 四瀆 
Disguised Subjectivity in Two Chinese Fictional Dream Narratives of the Qing

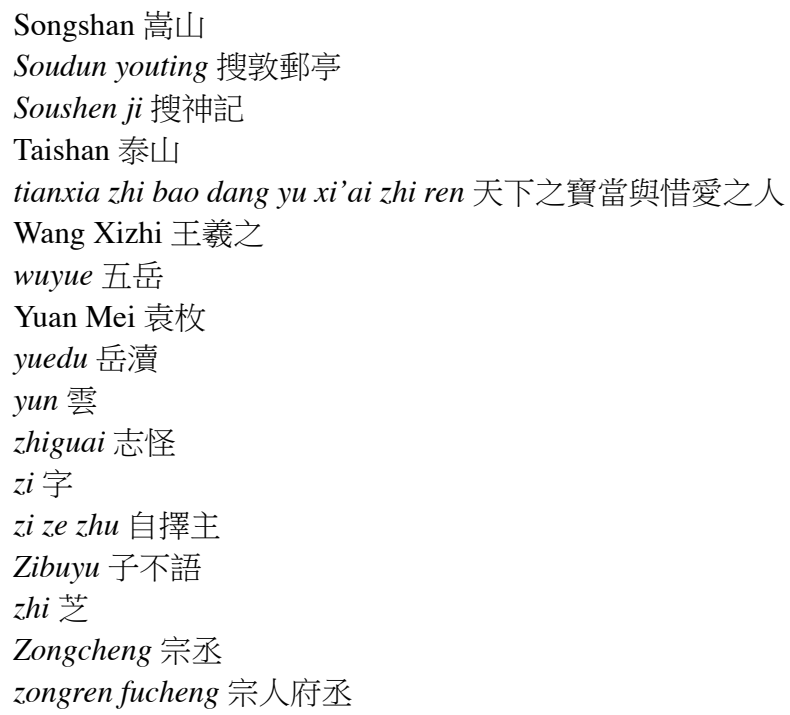

